\title{
"I Shall Never Forget": The Civil War in American Historical Memory, 1863-1915
}

Emily Tran

This essay examines the development of the social memory of the American Civil War in the first fifty years after the end of the war. During these decades, three major narratives emerged: a reconciliationist vision that emphasized the common heritage of the North and South and the valour of all soldiers; a white supremacist vision of white racial victory that championed terror and violence and eventually became a component of the reconciliationist vision; and the emancipationist vision, borne of African American remembrance and which conceived of the war as a rebirth of the Republic and the liberation of blacks to citizenship and equality. Moving chronologically through fifty years, I analyze the role of reconciliationist and emancipationist intellectuals, politicians, and organizations as they contested and shaped the enduring memory of the Civil War.

2015 marked the $150^{\text {th }}$ anniversary of the end of the American Civil War. However, as historian David W. Blight wrote in The Atlantic, even a century and a half after General Robert E. Lee surrendered to General Ulysses S. Grant at Appomattox, "the questions at the heart of the war ... still occupy the nation, which has never truly gotten over that conflict." The potency of the Civil War and its legacies became particularly evident in the summer of 2015, when white supremacist Dylann Roof killed nine people at Charleston, South Carolina's historic Emanuel African Methodist Episcopal Church. In the aftermath of the tragedy, renewed calls to remove the Confederate battle flag from the state's Capitol were met with resistance and defiance from those who claimed that the Civil War-era symbol represented "heritage not hate" and was an emblem of "a

\footnotetext{
${ }^{1}$ David Blight, "The Civil War Isn't Over," The Atlantic, 8 April 2015, http://www.theatlantic.com/politics /archive/2015/04/the-civil-war-isnt-over/389847/
} 
purely noble cause and proud heritage."2 Enmeshed in this perception of this symbol of the Confederacy was an understanding of the Civil War, the causes for which it was fought, and the enduring legacies of the war.

That an event so central to American history remains openly contested renders the Civil War of particular interest in the study of American social memory. The twenty-first century display of the Confederate battle flag atop state capitols, at sporting events, and on license plates and other trinkets is representative of a continued perception of the Civil War as the noble, gallant Lost Cause of the South, divorced from the racial violence of the institution of slavery. This interpretation of the Civil War is rooted in the immediate half century following the Civil War, when intellectuals, politicians, and veterans of the war openly contested the meaning of the conflict and the causes over which it was fought. Three major narratives emerged and combined or severed over time: a reconciliationist vision that emphasized the common heritage of the North and South and the valour of all soldiers; a white supremacist vision of white racial victory that championed terror and violence and eventually became a component of the reconciliationist memory; and the emancipationist vision, borne of African American remembrance and which conceived of the war as a rebirth of the Republic and the liberation of blacks to citizenship and equality. By the semi-centennial of the Civil War in the early $20^{\text {th }}$ century, reconciliation had overwhelmed emancipation in the national culture. $^{3}$ In seeking to understand the process by which reconciliation trumped emancipation in the years following the Civil War, it is useful to examine the major figures and institutions that promoted differing visions of the conflict.

David Thelen notes that the study of memory should "explore how people together searched for common memories to meet present needs, how they recognized such a memory and then agreed, disagreed, or negotiated over its meaning, and finally how they preserved and absorbed that meaning into their ongoing concerns." 4 As such, it is appropriate to not only consider those who constructed the historical memory of the Civil War in its aftermath, but also how these interpretations reflected contemporary concerns and were physically preserved through monuments. Moving chronologically from the Emancipation Proclamation in 1863 to semi-centennial celebrations of the war

\footnotetext{
2 Ta-Nehisi Coates, “Take Down the Confederate Flag - Now," The Atlantic, 18 June 2015. http://www.theatlantic.com/politics/archive/2015/06/take-down-the-confederate-flag-now/396290/; Yoni Appelbaum, "Why is the Flag Still There?" The Atlantic, 21 June 2015. http://www.theatlantic.com/politics/ archive/2015/06/why-is-the-flag-still-there/396431/

3 David W. Blight, Race and Reunion: The Civil War in American Memory (Cambridge, MA: Belknap Press, 2001), 2.

4 David Thelen, “Memory and American History.” Journal of American History 75, no. 4 (March 1989): 1123.
} 
in 1913-1915, this analysis examines the pivotal role of reconciliationist and emancipationist intellectuals, politicians, organizations, and veterans in deciding the meaning and shaping the enduring memory of the Civil War.

The meaning of the Civil War broadened considerably when President Abraham Lincoln issued the Emancipation Proclamation on 1 January 1863. Previously, Lincoln's mission in waging war had been to preserve the Union; the Emancipation Proclamation expanded the purpose of war to the emancipation of slaves. ${ }^{5}$ As Eric Foner notes, the Proclamation "represented a turning point in national policy" by associating Union victory with abolition and "transformed a war of armies into a conflict of societies." Now, the defeat of the Confederacy would bring the end of slavery and the commencement of a social revolution in which men black and white would be equally free. In his Gettysburg Address of November 1863, Lincoln provided an ideological explanation for the war that acknowledged this fundamental shift. Invoking the Declaration of Independence's proposition that "all men are created equal," Lincoln's declared, "We are engaged in a great civil war, testing whether that nation, or any nation so conceived and so dedicated, can long endure." For Lincoln, the war had become a struggle for "a new birth of freedom" rooted in equality for all people in a nation governed by all people. ${ }^{8}$ It was this idea that would form the basis of the emancipationist memory of the war, and would be defiantly rejected by reconciliationist memory.

The emancipationist vision of the Civil War was powerfully displayed in Charleston, South Carolina in the final weeks of war. Heavily bombarded by Union artillery, the city had been evacuated in February of 1865 and the majority of those who remained were black Charlestonians. On 29 March, after the city had fallen to Union troops, these African Americans organized a festive parade of four thousand people. The first float carried an auctioneer selling two black women and their children. Behind it, the second float carried a coffin painted with the words "Death of Slavery - Sumter Dug His Grave on the $13^{\text {th }}$ of April, 1861." In staging this parade marking the "Death of Slavery" and celebrating the dawn of black freedom from bondage, these black Charlestonians

${ }^{5}$ Blight, Race and Reunion, 15.

${ }^{6}$ Eric Foner, Reconstruction: America's Unfinished Revolution 1863-1877. (New York: Harper \& Row, 1988), 7.

7 “The Gettysburg Address,” Abraham Lincoln Online, accessed 5 April 2015, http://www.abrahamlincoln online.org/lincoln/speeches/gettysburg.htm

8 Blight, 13. 
declared the meaning of the war, and centered the conflict as a marker between the slavery of the past and the freedom of the present. ${ }^{9}$

While, in the 1860s, Lincoln and black Charlestonians powerfully conveyed the emancipationist meaning of the war as a battle for the notion of equality and for the end of slavery, the failures of the Reconstruction era would prove to be foundational for the reconciliationist interpretation of the conflict. The economic depression of the $1870 \mathrm{~s}$, a stagnation in demand for cotton, a weakened and less affluent planter class, political factionalism and corruption, the failure of Republicans to appeal to white voters, and growing racial animosity sowed further discontent throughout a defeated and defiant South. ${ }^{10}$ In the 1872 election, newspaper editor Horace Greeley led a third-party coalition of Democrats and dissident Republicans and positioned himself firmly against Ulysses S. Grant and Reconstruction. Greeley proclaimed that "the basis of a new, beneficent National Reconstruction" would be founded in "a New Departure from the jealousies, strifes, and hates, which have no longer adequate motive or even plausible pretext." Despite Greeley's defeat, his urging of Northerners and Southerners to "clasp hands across the bloody chasm which has too long divided them" proved persuasive. ${ }^{11}$ Many Northerners began to view Southerners more sympathetically and support waned for federal intervention on behalf of former slaves. ${ }^{12}$

Northern pity for Southerners was especially concentrated on sentiment for the planter class and, as Nina Silber has argued, was partially founded in the Victorian ethic of suffering. Victorian Americans believed that suffering "represented a genuine emotion which cut through economic and political pretenses and revealed true human feeling," and felt that "those who suffered, as well as those who were sympathetic to suffering, were emotional and caring people, not just vicious competitors in the public sphere.",13 Thus, Northerners' recognition of the Southern upper class suffering and loss amidst the upheaval of Reconstruction could be considered a mix of both genuine sentiment and self-serving magnanimity. Pity for Southerners was also founded in Northerners' scapegoating of black politicians and voters who, Northerners believed, profited from

${ }^{9}$ David W. Blight, "Healing and History: Battlefields and the Problem of Civil War Memory," in Beyond the Battlefield: Race, Memory, and the American Civil War, ed. David W. Blight (Boston: University of Massachusetts Press, 2002), 183-184.

${ }^{10}$ Foner, Reconstruction, 603.

11 William Mason Cornell, The Life and Public Career of Hon. Horace Greeley (Boston: Lee and Shepard, 1872), 304.

12 Eric Foner, "Selective Memory: A historian studies how Reconstruction influenced the legacy of the Civil War in America." New York Times. 4 March 2001. https://www.nytimes.com/books/01/03/04/reviews/ 010304.04fonert.html

13 Nina Silber, The Romance of Reunion: Northerners and the South, 1865-1900 (Chapel Hill, NC: University of North Carolina Press, 1993), 51. 
the corrupt and questionable policies of the Reconstruction period. ${ }^{14}$ Northerners also learned to sympathize with former Confederate soldiers, having concluded that, more than any other Southerner, the common soldier had been well acquainted with suffering and hardship during the war; in fact, the Confederate soldier was particularly tragic because unlike Yankee soldiers, his suffering had been in vain. ${ }^{15}$ Even General Robert E. Lee was deemed worthy of respect and admiration. In Lee's 1870 obituary, the New York Times commended the Confederate general for his "unobtrusive modesty and purity of life" which had "won the respect even of those who most bitterly deplore and reprobate his course in the rebellion."16 This Northerner embrace of sentiment and reconciliation with a suffering, pitiable South paved the way for a discourse of intersectional reunion and the abandonment of political and economic solutions in the South. ${ }^{17}$

As Northerners moved towards reconciling with the South, they also prided themselves on their ability to forget the recent past. In 1878, an editorial in the New York Times criticized abolitionist William Lloyd Garrison for being "unable to forget." "Does he really imagine," the writer questioned, "that outside of small and suspicious circles any real interest attaches to the old forms of the Southern question?" "[T] we have had with the South ought not be allowed to interfere" with new political goals, the writer declared, before labeling Garrison an anachronism set on "dig[ging] up the errors and faults of the past as pretexts for dissensions that will be increase the [Republican] party's weakness." ${ }^{18}$ Over the course of this first postwar decade, progress and statesmanship had come to be attributed with forgetting the past and moving ceaselessly forward. In keeping with Reconstruction-era notions of progress and expansion, the embrace the future of growth and development required the forgiving and forgetting of sectional hostilities. ${ }^{19}$

While white Northerners were quick to embrace sentimentality and reconciliation in the aftermath of the war, black Americans continued to advance the emancipationist vision of the war and seek public recognition of their history. In April 1878, the unveiling of the Freedmen's Memorial Monument to Abraham Lincoln in Washington, D.C. brought together President Ulysses S. Grant, his cabinet, Supreme Court Justices, senators, and

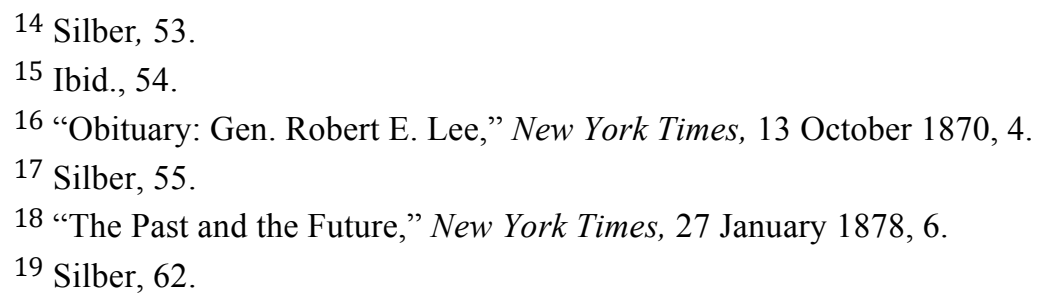


African American leaders including Frederick Douglas. The monument had been commissioned by and paid for nearly entirely by blacks, and stood not only in honour of Lincoln but as a testament to the Emancipation Proclamation. ${ }^{20}$ In Douglas' keynote address, he asserted the citizenship of black Americans and place of blacks in the nation, saying "When now it shall be said that the colored man is soulless . . . when the foul reproach of ingratitude is hurled at us, and it is attempted to scourge us beyond the range of human brotherhood, we may calmly point to the monument we have this day erected to the memory of Abraham Lincoln." 21 For Douglas this monument, and the wartime actions of man whom it honoured, affirmed the place of African Americans and their emancipation in American history and in American national memory.

In the 1880s, white Northerners' sentimentalism and spirit of sectional reunion was complemented by the rise of the Lost Cause mentality in the American South. Historiographical interpretations of the Lost Cause fall into three general strains: as public memory, shaped by organizations and institutions; as civil religion, steeped in religious rhetoric and secular thought; and as a literary phenomenon, shaped by journalists and fictional writers. Scholars have also divided the Lost Cause into two movements: the "inner" Lost Cause which rose to prominence during the 1870s and 1880s; and the "national" Lost Cause, which arose later in the 1890s. ${ }^{22}$ A central figure of the "inner" Lost Cause was Jefferson Davis, who had been President of the Confederate States during the Civil War. In 1881, Davis published his 1 279-page memoir, The Rise and Fall of the Confederate Government, in which he outlined what he viewed to be the causes of the Civil War and placed the culpability for secession completely at the feet of the North. According to Davis, the South had simply been protecting itself against a despotic federal government and "to whatever extent the question of slavery may have served as an occasion, it was far from being the cause of the conflict." 23 This disavowal of slavery as a key component of the Confederate cause would become "almost omnipresent" in Lost Cause rhetoric, and Blight credits Davis' polemics with "giv[ing] the Lost Cause its lifeblood." 24

${ }^{20}$ David W. Blight, ““'For Something Beyond the Battlefield”: Frederick Douglas and the Struggle for the Memory of the Civil War," Journal of American History 75, no. 4 (March 1989), 1164.

${ }^{21}$ Frederick Douglas, "Oration in Memory of Abraham Lincoln," Teaching American History, accessed 5 April 2016, http://teachingamericanhistory.org/library/document/oration-in-memory-of-abraham-lincoln/

22 Blight, "Frederick Douglas," 1166-1167.

23 Jefferson Davis, "Slavery not the cause, but an incident," in The Confederate and Neo-Confederate Reader: The "Great Truth" about the "Lost Cause," edited by James W. Loewen and Edward H. Sebesta (Jackson, MS: University Press of Mississippi, 2010), 271.

${ }^{24}$ Blight, 259-260. 
The growing popularity and dissemination of Lost Cause and reconciliationist rhetoric through the 1870s into the1880s was not met without resistance. In 1884, novelist and satirist Albion Tourgée mocked contemporary sentiment, writing "History hath already recorded it with more or less exactitude. It was long and fierce because two brave peoples fought with the desperation of conviction. ... It was a wonderful conflict.",25 Regarding the Civil War, Tourgée urged the American people to remember "not the courage, the suffering, the blood, but only the causes the underlay the struggle and the results that followed from it." 26 Frederick Douglas, who had after the war turned his attentions to preserving and publicizing an emancipationist memory of the Civil War, decried the "tide of popular prejudice" against black Americans that had "swollen by a thousand streams" since the war. "It is weak and foolish to cry PEACE when there is no peace," he declared, "In America, as elsewhere, injustice must cease before peace can prevail." ${ }^{27}$ Douglas also criticized the Lost Cause's concealment of the Confederacy's war objectives: "Whatever else I may forget, I shall never forget the difference between those who fought for liberty and those who fought for slavery; between those who fought to save the Republic and those who fought to destroy it." ${ }^{28}$ For both Tourgée and Douglas, the dominance of reconciliationism and the Lost Cause in American memory of the Civil War served only to conceal the deep schism at the heart of the war, which had not yet healed nor yielded justice to black Americans.

Throughout the $1880 \mathrm{~s}$ into the $1890 \mathrm{~s}$, the voices of Douglas and Tourgée were far outmatched by public enthusiasm for national reconciliation and the Lost Cause. In May of 1890, the national traction of the Lost Cause movement was thrown into stark relief with the unveiling of a giant statue of General Robert E. Lee astride his horse, which loomed over what would become Monument Avenue in Virginia. This monument honoured a Confederate general who had, since his death in 1870 , been lionized by former Confederate officers and veterans associations into a "blameless Christian soldier, a paragon of manly virtue and duty who soared above politics." 29 The statue's unveiling was attended by a crowd of more than 100000 people, the air punctuated by "Dixie" and other Southern tunes, the sidelines of the parade marked by Confederate and United States flags. The legend of General Lee had now grown to national proportions,

${ }^{25}$ Albion W. Tourgée, An Appeal to Caesar (New York, 1884), 37, quoted in Blight, "Frederick Douglas," 1163.

26 Ibid.

27 Frederick Douglas, "Speech at the Thirty-Third Anniversary of the Jerry Rescue," quoted in Blight, "Frederick Douglas," 1171.

28 "Decoration Day," May 1894, reel 17, Douglas Paper, quoted in Blight, "Frederick Douglas," 1178." 29 Blight, 267. 
and the new monument was praised in newspapers throughout the country. The New Orleans Picayune wrote that Lee was "the truest of Americans" who belonged to the nation's "common heritage;" the New York Times declared that Lee's memory was "a possession of the American people, and the monument ... a National possession." ${ }^{30}$ That this monument of Lee, a Confederate general, could be considered a "National possession" worthy of veneration from both Northerners and Southerners indicates the degree to which the Lost Cause ideology had permeated American national culture and memory.

The strength and ubiquity of the Lost Cause in the 1890s can be attributed to the three major institutions: the Confederate Veteran magazine, the United Confederate Veterans, and the United Daughters of the Confederacy. The Confederate Veteran was a Nashville-based periodical, founded in 1893 by Sumner A. Cunningham. ${ }^{31}$ By 1900, the magazine reached a circulation of 20000 in 41 states, two territories, and the District of Columbia. ${ }^{32}$ According to Cunningham, the magazine was not a "bitter" publication, but would rather "vindicate the truth of history at all hazards." ${ }^{33}$ Confederate Veteran attracted poems, war records, and reminiscences from Confederate veterans and their families. Cunningham made white supremacy a key component of his publication, actively seeking tributes to "faithful slaves" and denouncing Reconstruction-era efforts for racial equality. For Cunningham, even the phrases "Lost Cause" and "New South" were not sufficient in vindicating the Confederacy for they hinted at loss. "No! No! Our cause was not lost because it was wrong," he proclaimed in the pages of the Confederate Veteran, "No! No! Our cause was not lost for the reason that it was not wrong." ${ }^{34}$ As a widely circulated mouthpiece for the Confederate wartime cause and as a medium for Confederate reminiscing of the antebellum past, the Confederate Veteran was a significant force in the establishment of the Lost Cause mythology in the American historical conscience.

From its very first issue, the Confederate Veteran was circulated to every Confederate Veteran organization, whose patronage was "earnestly sought," indicating the close relationship between the magazine and the United Confederate Veterans (UCV). ${ }^{35}$ The UCV was established in 1893 as part of efforts to amalgamate local Confederate

30 New Orleans Picayune, 30 May 1890, quoted in Blight, Race and Reunion, 270; "The Lee Statue Unveiled, Thousands of Veterans Honor His Memory," New York Times, 30 May 1890, 1.

31 Blight, Race and Reunion, 272.

32 Ibid., 456.

33 S.A. Cunningham Papers, quoted in Blight, 277.

34 "Terms as to who was 'Right' Etc.," Confederate Veteran 17 (July 1909), 313.

35 "The Confederate Veteran Greets You!” Confederate Veteran 1(1893), 1. 
veterans organizations. At the peak of the movement in 1903, an estimated 85000 members were spread across more than 1500 local camps. In the 1890s, the UCV provided comradeship and celebration of Lost Cause rituals amidst the trials of economic hardship and political turmoil. ${ }^{36}$ Closely related to the UCV was the United Daughters of the Confederacy (UDC), which by 1900 counted 17000 members in 20 states and territories. The UDC, composed primarily of patrician women, raised money to build Confederate monuments, monitored the content of history textbooks, distributed scholarships to the grandsons and granddaughters of Confederate veterans, hosted historical essay contests for youth, and campaigned for the Civil War to be officially renamed the "War between the States." ${ }^{37}$ Both the UDC and the UCV fostered in the American historical conscience and in Southern public culture a new ideology of the Lost Cause. As Blight explains, this new Lost Cause glorified the valour of Confederate soldiers, used the Confederate past as a defence from the political and social upheaval of the 1890s, established history committees to guard the Lost Cause conception of Civil War history from criticism, argued about the causes of the war in the vein of Jefferson Davis, and utilized the image of the "faithful slave," thus racializing Civil War memory for the new generation. ${ }^{38}$

The United Daughters of the Confederacy was, perhaps, the most influential body in shaping public memory of the Civil War in fifty years following Appomattox. In 1899, the UDC began endorsing pro-Southern textbooks in schools, defending their Lost Cause mythology from supposed Yankee influence and corruption. UDC women delivered public speeches, wrote in newspapers, published books, and lobbied Congress. In exerting considerable influence over places of education and in the home, these women firmly cemented in Southern public and private memory a mythic history of the Civil War in which a victimized South fought for Constitutional principles and defended a society of benevolent masters and content African slaves. ${ }^{39}$

Beginning at the turn of the century, the United Daughters of the Confederacy began a campaign to publically establish their mythology of contented, faithful slaves throughout the nation. Their campaign was based on an 1896 monument in Fort Mill, South Carolina built by Confederate veteran Samuel E. White. White's monument, an obelisk with faces depicting a mammy and a male labourer, was

\footnotetext{
36 Blight, 272.

37 Ibid., 273.

38 Ibid., 274.

${ }^{39}$ Ibid., 278.
} 
Dedicated to the Faithful Slaves who, loyal to a sacred trust, Toiled for the support of the Army with matchless Devotion, and with sterling fidelity guarded our defenseless homes, women, and children during the struggle for the principles of our 'Confederate States of America., 40

In 1905, the UDC began a twenty year-long campaign to erect a "mammy memorial" like that in Fort Mill in every state, with a national mammy memorial in the nation's capital. "Erecting this monument," wrote Mary M. Solari of a UDC chapter in Memphis, "would influence for good the present and coming generations, and prove that the people of the South who owned slaves valued and respected their good qualities as no one else every did or will do." 41 Though this campaign ultimately failed in the World War I-era, that it continued for twenty years and even passed deliberation in the Senate speaks to the success of the UDC in establishing in the nation's collective memory the mythology of the faithful slave loyal to the Southern cause. ${ }^{42}$

In 1913, to mark semi-centenary of the Battle of Gettysburg, more than 53000 Confederate and Union veterans gathered in Gettysburg for the Peace Jubilee. "The Great Camp" which housed the veterans from 1-4 July covered 280 acres and was staffed by 2170 cooks who served 688000 meals. ${ }^{43}$ This publically funded ritual was a festival of reconciliation and reunion, and on the last day of the pageant newly inaugurated President Woodrow Wilson, the first Southern-born president since the Civil War, declared, " How wholesome and healing the peace has been! We have found one another again as brothers and comrades ... the quarrel forgotten - except that we shall not forget the splendid valor, the manly devotion of men then arrayed against one another, now grasping hands and smiling into each other's eyes."44 Wilson's rhetoric, like the public memory his words aptly reflected, bypassed any mention of the causes or the consequences of the Civil War, of slavery, or of racial equality. Instead, only the valour and devotion of soldiers - all soldiers - was worthy of mention in this presidential endorsement of reconciliationist memory. No black veterans attended the Gettysburg Peace Jubilee, save for those who worked as camp labourers, building the

40 Blight, 288.

41 Mary M. Solari, "Monument to Faithful Slaves" Confederate Veteran 13 (March 1905), 123-124.

42 Blight, Race and Reunion, 288.

43 David W. Blight, "A Quarrel Forgotten or a Revolution Remembered? Reunion and Race in the Memory of the Civil War 1875-1913," in Beyond the Battlefield: Race, Memory, and the American Civil War, edited by David W. Blight (Boston: University of Massachusetts Press, 2002):135.

44 The Papers of Woodrow Wilson, ed. Aruthur Link (Princeton: Princeton University Press), 28, quoted in Blight, "A Quarrel Forgotten," 138. 
tent city and distributing supplies. ${ }^{45}$ Fifty years in the wake of the war which had freed them from the bondage of slavery, this reconciliation of North and South, and the broader American national memory of the Civil War, made no place for African Americans.

On 28 August 1963, one hundred years after Lincoln's signing of the Emancipation Proclamation, Martin Luther King, Jr. stood on the steps of the Lincoln Memorial in Washington, D.C. and delivered his momentous "I Have a Dream" speech to a crowd of 250 000. Recalling the Emancipation Proclamation as a "beacon of hope to millions of Negro slaves," King remarked, "one hundred years later, the Negro is still not free." King's speech drew a direct connection between the emancipationist memory of the Civil War and the continuing Civil Rights Movement for black equality. The day King imagined, when African Americans would be "Free at last," had not been possible in the one hundred years since the Civil War, marked as it was by the reconciliationist memory advanced by organizations, political leaders, Southern publications, and Confederate veterans that vaulted over the deep racial legacies of the war. Indeed, it is only through true reconciliation, in which the "bloody chasm" crossed is not just between the North and South but between black and white, that Americans can acknowledge and address the deeply consequential legacies of the Civil War.

45 Blight, 385.

46 Martin Luther King, Jr. "I Have a Dream,” American Rhetoric, accessed 5 April 2016, http://www.americanrhetoric.com/speeches/mlkihaveadream.htm 


\section{Bibliography}

Applebaum, Yoni. “Why is the Flag Still There?” The Atlantic. 21 June 2015. http://www.theatlantic.com/politics/archive/2015/06/why-is-the-flag-stillthere/396431/

Blight, David W. "The Civil War Isn't Over.” The Atlantic. 8 April 2015. http://www.theatlantic.com/politics/archive/2015/04/the-civil-war-isntover/389847/

_. "“For Something Beyond the Battlefield": Frederick Douglas and the Struggle for the

Memory of the Civil War.” Journal of American History 75, no. 4 (March 1989): 11561178.

—_. "Healing and History: Battlefields and the Problem of Civil War Memory." In Beyond the

Battlefield: Race, Memory, and the American Civil War, edited by David W. Blight, 170-190. Boston: University of Massachusetts Press, 2002.

__ . "A Quarrel Forgotten or a Revolution Remembered? Reunion and Race in the Memory

of the Civil War 1875-1913." In Beyond the Battlefield: Race, Memory, and the American Civil War, edited by David W. Blight, 120-152. Boston: University of Massachusetts Press, 2002.

- Race and Reunion: The Civil War in American Memory. Cambridge, MA: Belknap Press, 2001.

Coates, Ta-Nehisi. "Take Down the Confederate Flag - Now." The Atlantic. 18 June 2015. http://www.theatlantic.com/politics/archive/2015/06/take-down-theconfederate-flag-now/396290/

“The Confederate Veteran Greets You!” Confederate Veteran 1(1893): 1.

Cornell, William Mason. The Life and Public Career of Hon. Horace Greeley. Boston: Lee and Shepard, 1872. 
Douglas, Frederick. "Oration in Memory of Abraham Lincoln." Teaching American History. Accessed 5 April 2016. http://teachingamericanhistory.org/library/document/oration-in-memory-ofabraham-lincoln/

Foner, Eric. Reconstruction: America's Unfinished Revolution 1863-1877. New York: Harper \& Row, 1988.

—_. "Selective Memory: A historian studies how Reconstruction influenced the legacy of the Civil War in America." New York Times. 4 March 2001. https://www.nytimes.com/books /01/03/04/reviews/010304.04fonert.html

“The Gettysburg Address." Abraham Lincoln Online. Accessed 5 April 2016. http://www.abra hamlincolnonline.org/lincoln/speeches/gettysburg.htm

King, Martin Luther "I Have a Dream." American Rhetoric. Accessed 5 April 2016. http://www.americanrhetoric.com/speeches/mlkihaveadream.htm

"The Lee Statue Unveiled: Thousands of Veterans Honor His Memory.” New York Times. 30 May 1890, 1.

Loewen, James W. and Edward H. Sebesta, eds. The Confederate and Neo-Confederate Reader: The "Great Truth" about the "Lost Cause." Jackson, MS: University Press of Mississippi, 2010.

“Obituary: Gen. Robert E. Lee.” New York Times. 13 October 1870, 4.

“The Past and the Future." New York Times. 27 January 1878, 6.

Silber, Nina. The Romance of Reunion: Northerners and the South, 1865-1900. Chapel Hill, NC: University of North Carolina Press, 1993.

Solari, Mary M. "Monument to Faithful Slaves" Confederate Veteran 13 (March 1905): $123-124$.

“Terms as to who was 'Right' Etc." Confederate Veteran 17 (July 1909): 313.

Thelen, David. "Memory and American History." Journal of American History 75, no. 4 (March 1989): 1117-1129. 